\title{
АНТИКОРУПЦІЙНІ ЗАХОДИ ПРИ ПОБУДОВІ НОВОЇ СИСТЕМИ ОХОРОНИ ЗДОРОВ'Я: ДОСВІД РЕСПУБЛІКИ ПОЛЬЩА
}

\author{
ДВНЗ «Тернопільський державний медичний університет імені І.Я. Горбачевського \\ МОЗ України»
}

\begin{abstract}
Мета: проаналізувати антикорупційне законодавства у сфері медичної діяльності щодо доцільності впровадження медичного страхування при побудові нової національної системи охорони здоров'я.

Матеріали і методи. Вивчалося національне законодавство України, законодавство Республіки Польща; використано порівняльно-правовий метод та інші загальнонаукові та спеціальні методи наукового пізнання.

Результати. Одним із антикорупційних заходів у системі охорони здоров'я є запровадження загальнообов'язкового соціального медичного страхування. Наступними етапами є: встановлення ефективного контролю над фінансуванням системи охорони здоров'я; прийняття Закону України «Про загальнообов'язкове соціальне медичне страхування» та створення умов для його запровадження з відповідними змінами податкового законодавства; стимулювання розвитку державного медичного страхування.

Висновки. Запропонована система заходів, спрямованих на запровадження і розвиток медичного страхування в Україні, дозволить створити умови для найбільш повного задоволення потреб населення в доступній і високоякісній медичній допомозі; суттєво зменшити навантаження на державний та місцеві бюджети; зменшити частку тіньової медицини у системі медичного забезпечення; уникнути необґрунтованих витрат; покращити матеріальну мотивацію працівників.
\end{abstract}

КЛЮЧОВІ СЛОВА: корупція, правопорушення, медичне страхування, система охорони здоров'я.

Розбудова України як демократичної, правової держави була і є одним з найпріоритетніших напрямів державної політики. Передумовою успішної реалізації нових реформ слід вважати боротьбу з корупцією. Корупція, як суспільне явище, зумовлена періодичним характером та залежністю від політичної ситуації. В умовах сьогодення це явище становить вагому загрозу національній безпеці та має комплексний, системний характер. За даними міжнародної організації Transparency International, Україна займає 144 місце у рейтингу серед країн світу за рівнем корумпованості в органах державної влади [5].

Поступове впровадження європейських стандартів забезпечення права громадян на медичну допомогу, утвердження здорового способу життя є першоосновою забезпечення в установленому порядку програми реформування системи охорони здоров'я. Натомість низький рівень бюджетного фінансування медичних закладів в Україні, відсутність законодавчої бази щодо додаткових джерел фінансування медичної галузі провокує недостатність як оновлення технічного обладнання, так і забезпечення хворих медикаментами. Це, в свою чергу, формує у пацієнтів негативне ставлення до якості надання медичної допомоги населенню та є підґрунтям для корупційних правопорушень у сфері медичної діяльності.

Потреба у радикальному реформуванні медичної галузі зумовлена, насамперед, високим

(C) I.О. Рогальський, Н.M. Калинюк, 2015 рівнем бюрократизації і централізації системи управління 3 відсутністю самоврядування суб'єктів на ринку охорони здоров'я. Саме структурна неефективність галузі, низький рівень координації управління, залишковий принцип фінансування галузі, неналежне впровадження механізмів, що гарантують якість надання медичної допомоги, у тому числі й недосконалість чинного законодавства щодо відповідальності медичного працівника за якість надання медичної допомоги, є першоджерелом корумпованості у медичних правовідносинах.

Метою даної статті є здійснення аналізу антикорупційного законодавства у сфері медичної діяльності у контексті доцільності впровадження страхової медицини при побудові нової системи охорони здоров'я.

Матеріали і методи. У роботі вивчалося національне законодавство України, законодавство Республіки Польща; використано порівняльноправовий метод та інші загальнонаукові та спеціальні методи наукового пізнання.

Результати дослідження та їх обговорення. Зміни до чинного Закону України «Про засади запобігання та протидії корупції в Україні» [8] свідчать про актуальність вивчення досвіду європейських країн, зокрема Республіки Польща, у контексті введення страхової медицини в Україні як одного зі способів протидії корупції. Досліджуючи означену проблематику, необхідно розглянути розуміння поняття корупції за міжнародними 
нормативно-правовими актами. Першу спробу визначення правової природи корупційного діяння у міжнародних нормах здійснено у Практичних заходах боротьби з корупцією, пропонованих Економічною та Соціальною Радами Секретаріату ООН. Відповідно до Резолюції ООН, корупційне діяння слід розуміти як одержання хабара тією чи іншою особою, а також крадіжки, розкрадання або присвоєння державної власності з метою приватного використання, зловживання посадовим становищем з метою одержання неправомірної винагороди або окремих переваг. Іншими словами, це будь-яке заплановане, передбачуване, необхідне або успішне отримання пільг у результаті необґрунтованого використання офіційного статусу та конфлікт інтересів протиріччя між службовими обов'язками та особистими інтересами [6].

У ст. 4. Закону України «Про засади запобігання та протидії корупції в Україні» до суб'єктів відповідальності за корупційні правопорушення віднесено категорію посадових осіб юридичних осіб публічного права. Юридична практика тлумачення цього поняття вказує на те, що посадовими особами слід вважати осіб, які обіймають посади, пов'язані з виконанням організаційнорозпорядчих та консультативно-дорадчих функцій [7]. Водночас наведене тлумачення $€$ вузькоспеціалізованим, оскільки стосується державних службовців. Однак, відповідно до Постанови Верховного Суду України від 26 квітня 2002 р. №5, визначено, що на посадових осіб юридичної особи публічного права поширюється й виконання адміністративно-господарських обов'язків, тобто обов'язків з управління або розпорядження державним, колективним чи приватним майном [10].

Наведене дає підстави для висновку про те, що медичні спеціалісти є суб'єктами відповідальності за корупційні правопорушення, якщо вони працюють у державних чи комунальних закладах охорони здоров'я та відповідають хоча б одній із зазначених ознак: мають у підпорядкуванні хоча б одну особу; здійснюють функції з розпорядження чи адміністрування діяльності (включаючи й консультативно-дорадчі). Наприклад, до таких категорій посадових осіб можна віднести головного лікаря та його заступників, завідувача відділення та інших, які працюють у комунальних лікувально-профілактичних закладах.

Значний внесок у дослідження проблематики боротьби із корупцією у зарубіжних країнах, у тому числі шляхом впровадження обов'язкового медичного страхування у галузі охорони здоров'я, зробили О. Бусол, І. Гайка, М. Погорецький, Б. Романюк, О. Санчес, І. Бочарников, Г. Клеменчич, О. Крук, Р. Мауро, Я. Стусек, І. Чубенко та інші вчені.
Інтерес до вивчення позитивного досвіду Республіки Польща у боротьбі з корупцією в галузі охорони здоров'я зумовлений спільними рисами України та Польщі, як європейських країн, з культурних, територіальних, ментальних ознак.

Феноменом корупції у Республіці Польща було те, що сектор охорони здоров'я належав до найбільш корумпованих сфер суспільного життя. З цих причин у 1999 р. в Польщі шляхом усунення корумпованих діянь у галузі медицини вбачалося саме впровадження обов'язкового страхування. Підґрунтям для запровадження страхової медицини була децентралізація фінансування сфери охорони здоров'я завдяки створенню Національного та територіальних фондів, наділених управлінськими повноваженнями з питань визначення напрямів асигнувань та розподілу наявних коштів у медичній діяльності (принцип реінбурсації). I хоча реформа надала адміністраціям регіональних фондів досить значні повноваження, проте негативний моментом їі проведення була відсутність дієвого механізму нагляду за їх діяльністю. Так, декларативно, фінанси повинні були надходити на медичне обслуговування пацієнтів. Однак на практиці їх використання було неможливим через обмеження шляхом встановлення кількості діагностичних процедур та операцій заздалегідь. Це зумовлювало довготривалий простій медичного обладнання та введення системи неофіційних платежів за медичні послуги [1].

На основі порівняльного аналізу нормативноправової бази Республіки Польща та України у сфері регулювання охорони здоров'я спробуємо на прикладі корупційних схем встановити значення страхової медицини в Україні для підвищення надання медичної допомоги населенню та обґрунтувати доцільність впровадження страхової медицини саме як способу подолання корупції з метою побудови в Україні нової національної системи охорони здоров'я.

У Республіці Польща, як і в Україні, найбільш поширені корупційні діяння у відносинах між пацієнтами та закладами охорони здоров'я, зокрема медичними працівниками. У 90-х роках XX століття у Республіці Польща було сформовано «фонд розвитку лікарень». Хоча законодавством Республіки Польща й передбачено надання безоплатної медичної допомоги у закладах охорони здоров'я державної форми власності, однак фактично повноваження даного фонду зводилися до примусового збору грошових коштів з пацієнтів цих закладів.

Закон Республіки Польща «Про лікувальну діяльність» №11/654 від 15 квітня 2011 р. містить положення про те, що особам надається право на безкоштовне користування послугами лікувальних суб'єктів, що не є підприємцями в ро- 
зумінні положень про лікувальну діяльність [9]. Система медичного страхування в Польщі ґрунтується на рівності доступу громадян та соціальної солідарності, забезпечення застрахованій особі вільного доступу до медичної допомоги, а також іï права вибирати лікаря та заклад охорони здоров'я. Реалізація означених засад здійснювалася за допомогою: зосередження коштів державного та місцевих бюджетів, страхових внесків громадян у новоствореному Фонді; диференційованого підходу до сплати страхових внесків; введення обов'язкового медичного страхування для окремих категорій працівників, наприклад, для галузі сільського господарства; загальнодоступність закладів охорони здоров'я до баз даних платників податків.

У ст. 49 Конституції України передбачено право кожного громадянина на охорону здоров'я, медичну допомогу та медичне страхування. Охорона здоров'я забезпечується державним фінансуванням відповідних соціально-економічних, медико-санітарних та оздоровчо-профілактичних програм. Держава створює умови для ефективного і доступного для всіх громадян медичного обслуговування. У державних і комунальних закладах охорони здоров'я медична допомога надається безоплатно; існуюча мережа таких закладів не може бути скорочена. Держава сприяє розвитку лікувальних закладів усіх форм власності [2].

Аналіз норм чинного законодавства Республіки Польща та України дає підстави стверджувати про наявність в обох державах принципу надання особам безоплатної медичної допомоги та права на медичне страхування. Однак страхова медицина в Україні не має належного правового регулювання, а у Республіці Польща з 1999 р. розпочато впровадження страхової медицини.

Першоосновою впровадження медичного страхування слід вважати охорону здоров'я населення та забезпечення належного рівня життя. Адже основними причинами звернення пацієнтів до медичних закладів $є$ не превентивні заходи, а саме звернення за медичною допомогою в критичних випадках - гостре захворювання та невідкладна допомога. Запобігання цим явищам можливе шляхом запровадження гарантій якості надання медичних послуг, одним з яких і $є$ обов'язкове медичне страхування. Характерною ознакою страхування слід вважати прогнозованість, що гарантуватиме оплату медичного обслуговування пацієнта страховиком.

У контексті теми дослідження слід звернути увагу, що у Республіці Польща Національний Фонд визначає обсяги фінансування системи охорони здоров'я та ліміти для медичних установ, а також управляє внесками громадян, планує та укладає договори з постачальниками послуг охорони здоров'я. Сутність цих суспільних відносин полягає в укладенні строкових трудових договорів між медичними працівниками та Фондом, з чіткою вказівкою на оплату праці у відсотковому співвідношенні від кількості пацієнтів, що перебували на медичному обслуговуванні у лікарів. Особа, що потребує медичної допомоги, набувала права самостійної реєстрації у будь-якому закладі охорони здоров'я. Пільговим категоріям населення, перелік яких визначено чинним законодавством Республіки Польща (неповнолітні особи, жінки під час вагітності та у післяпологовий період, інваліди тощо), забезпечується право на отримання безоплатної медичної допомоги за рахунок держави.

Враховуючи зарубіжний досвід з питань впровадження обов'язкового медичного страхування і розуміння його як антикорупційного заходу у системі охорони здоров'я, необхідно звернути увагу на фінансово-економічну кризу в Україні. Зокрема вагомого значення у проблематиці впровадження обов'язкового медичного страхування набуває залежність між рівнем доходів населення, а отже його платоспроможністю, та рівнем готовності до запровадження страхової медицини.

Пілотним проектом на підготовчому етапі до обов'язкового медичного страхування у Республіці Польща та Україні слід вважати фонд «Лікарняна каса», умовами функціонування якого є внесення кожним жителем населеного пункту щорічного фіксованого іменного внеску. У результаті ці кошти заклад охорони здоров'я може використати в майбутньому на лікування конкретної особи або іншої особи (у випадку наявності письмової заяви власника внесків). Діяльність «Лікарняної каси» спрямована на залучення коштів населення для забезпечення медикаментозного, діагностичного обслуговування хворих в умовах стаціонару та на покращення надання послуг станцією швидкої медичної допомоги. У результаті стало можливим лікувати пацієнтів у республіканських та обласних медичних закладах, надавати консультації та проводити діагностику в амбулаторних умовах, надавати стоматологічні послуги (лікування та протезування зубів) [4].

Створені «лікарняні каси» частково вирішують проблему нестачі фінансування закладів охорони здоров'я, але не мають економічного підґрунтя діяльності та не захищають належним чином юридичні права як медиків, так і їхніх пацієнтів. На противагу цьому медичне страхування забезпечує громадянам при виникненні страхового випадку оплату вартості медичного обслуговування за рахунок коштів страхових резервів, а також фінансування профілактичних заходів.

Наведене дає підстави констатувати, що реформування медичної галузі у Республіці Польща 
розпочалось 01.01.1999 р. із вступом у дію закону про обов'язкове медичне страхування. Запровадження обов'язкового медичного страхування дало змогу медичній галузі країни перейти на нові, більш сучасні, технології, забезпечити пацієнтів невідкладною та плановою медичною допомогою, лікувальні заклади - високоякісними витратними матеріалами, сучасним діагностичним та лікувальним обладнанням, підготувати високопрофесійних фахівців. Органами державної влади було поєднано як приватне, так і державне страхування, що максимально згладило негативні боки обох систем та знизило рівень корумпованості у відносинах між медичними працівниками та пацієнтами.

\section{Висновки}

Одним із антикорупційних заходів у системі охорони здоров'я є запровадження загальнообов'язкового соціального медичного страхування. Це дозволяє вирішити ряд наступних завдань: забезпечення конкурентоздатності на ринку надання медичних послуг, що підвищить якість надання медичної допомоги і зменшить рівень корумпованості у сфері медичної діяльності, пов'язаної з медичним обслуговуванням населення; формування понятійного апарату щодо визначення обов'язкового мінімуму послуг медичного страхування; забезпечення державного контролю за використанням єдиних стандартів усіма медичними установами, що працюють у системі медичного страхування, незалежно від їх відомчої підпорядкованості та організаційноправової форми; створення уніфікованої оптимальної системи класифікації та ціноутворення на медичні послуги.

Запропонована система заходів, спрямованих на запровадження і розвиток медичного страхування в Україні, як одного зі способів подолання корупції, дозволить створити умови для найбільш повного задоволення потреб населення в одержанні доступної і високоякісної медичної допомоги; суттєво зменшити навантаження на дер- жавний та місцеві бюджети; зменшити частку тіньової медицини у системі медичного забезпечення; уникнути необґрунтованих витрат, викликаних наданням зайвих медичних послуг, з метою одержання додаткового прибутку; покращити матеріальну мотивацію працівників медичних установ [3].

Аналізуючи зарубіжний досвід, необхідно констатувати, що сьогодні у роботі системи охорони здоров'я Республіки Польща дотримано принципи рівного доступу до служб охорони здоров'я, рівності прав державних і приватних страхувальників, вільного вибору постачальників медичних послуг. Триває процес удосконалення системи медичного страхування, оскільки вона має багато слабких місць, що викликає таке явище, як корупція. Сьогодні продовжується робота із децентралізації державних виплат, створення правової основи для недержавних джерел фінансування системи охорони здоров'я, поліпшення якості управління.

Враховуючи вдалий досвід Республіки Польща у подоланні корупції в системі охорони здоров'я, Україні варто взяти за приклад механізм проведення у ній реформ у медичній галузі. Існує необхідність у прискоренні введення в Україні загальнообов'язкового державного медичного страхування, після чого має бути встановлений ефективний контроль над фінансуванням системи охорони здоров'я. Слід зазначити, що у Проекті Концепції нової національної системи охорони здоров'я України сформовано перші кроки до запровадження страхової медицини в Україні [3]. Зокрема передбачено прийняття Закону України «Про загальнообов'язкове соціальне медичне страхування», створення умов для запровадження загальнообов'язкового соціального медичного страхування з відповідними змінами податкового законодавства та стимулювання розвитку державного медичного страхування і залучення населення до співоплати наданої медичної допомоги.

\section{Список літератури}

1. Бусол О. Ю. Боротьба з шахрайством і корупцією в системі охорони здоров'я Польщі / О. Ю. Бусол, А. О. Мельник // Бюлетень охорони здоров'я. - 2010. -№ 23. - С. 115-122.

2. Конституція України : Закон України від 28.06.1996 № 254к/96-ВР // ВВР. - 1996. - № 30. - Ст. 14.

3. Концепція нової національної системи охорони здоров'я України : проект КМУ [Електронний ресурс]. - Режим доступу : http://www.moz.gov.ua/docfiles/dod_Pro_20140618_0.pdf. - Назва з екрану.

4. Миколайчук М. Страхова медицина в Україні: актуальність та готовність до неї населення [Електронний ресурс] / М. Миколайчук, В. Засадко, М. Тищенко. - Режим доступу : http://www.ukrbizn.com/strahovanie/327-strahovamedicina-v-ukrayin-aktualnst-ta-gotovnst-do-neyi-naselennya.html. - Назва з екрану.

5. Пояснювальна записка до проекту Закону України «Про спеціально уповноважений орган з питань запобігання та протидії корупції» № 269703 від 04.07.2013 р. [Електронний ресурс]. - Режим доступу : http://w1.c1.rada.gov.ua/ pls/zweb2/webproc34?id=\&pf3511=47777. - Назва з екрану.

6. Практичні заходи боротьби з корупцією, підготовлені Економічною та Соціальною Радами Секретаріату ООН Матеріали восьмого Конгресу ООН з попередження злочинності та поводження із правопорушниками. - Гавана, Куба. - 27 серпня - 7 вересня 1990. - Нью-Йорк : ООН, 1991. 
7. Про державну службу: Закон України від 16.12.1993 № 3723-XII // ВВР. - 1993. - № 52. - Ст.490.

8. Про засади запобігання і протидії корупції : Закон України від 07.04.2011 № 3206-VI [Електронний ресурс]. Режим доступу : http://zakon4.rada.gov.ua/laws/show/3206-17. - Назва з екрану.

9. Про лікувальну діяльність : Закон Республіки Польщі № 11/654 від 15 квітня 2011 р. [Електронний ресурс]. Режим доступу: http://isap.sejm.gov.pl/DetailsServlet?id=WDU20111120654. - Назва з екрану.

10. Про судову практику у справах про хабарництво : Постанова Верховного Суду України від 26.04.2002 № 5 [Електронний ресурс]. - Режим доступу : http://zakon0.rada.gov.ua/laws/show/v0005700-02. - Назва 3 екрану.

\section{АНТИКОРРУПЦИОННЫЕ МЕРЫ ПРИ ПОСТРОЕНИИ НОВОЙ СИСТЕМЫ ЗДРАВООХРАНЕНИЯ: ОПЫТ РЕСПУБЛИКИ ПОЛЬША \\ И.О. Рогальский, Н.М. Калинюк}

ГВУЗ «Тернопольский государственный медицинский университет имени И.Я. Горбачевского МЗ Украины»

Цель: проанализировать антикоррупционное законодательство в сфере медицинской деятельности относительно целесообразности внедрения медицинского страхования при построении новой национальной системы здравоохранения.

Материалы и методы. Изучалось национальное законодательство Украины, законодательство Республики Польша; использованы сравнительно-правовой метод и другие общенаучные и специальные методы научного познания.

Результаты. Одним из антикоррупционных мероприятий в системе здравоохранения являетсяч введение общеобязательного социального медицинского страхования. Следующими этапами являются: установление эффективного контроля над финансированием системы здравоохранения; принятие Закона Украины «Об общеобязательном социальном медицинском страховании» и создание условий для его внедрения с соответствующими изменениями налогового законодательства; стимулирование развития государственного медицинского страхования.

Выводы. Предложенная система мер, направленных на внедрение и развитие медицинского страхования в Украине, позволит создать условия для наиболее полного удовлетвороения нужд населения в доступной и высококачественной медицинской помощи; существенно уменьшить нагрузку на государственный и местные бюджеты; уменьшить долю теневой медицины в системе медицинского обеспечения; избежать необоснованных трат; улучшить материальную мотивацию работников.

КЛЮЧЕВЫЕ СЛОВА: коррупция, правонарушения, медицинское страхование, система здравоохранения.

\section{ANTI-CORRUPTION MEASERES IN CONSTRUCTING NEW HEALTH CARE: THE EXPERIENCE OF POLAND \\ I.O. Rogalskyy, N.M. Kalyniuk}

SHEI "I.Y.Horbachevsky Ternopil State Medical University of the Ministry of Public Health of Ukraine"

Objective: to analyze the anti-corruption legislation in the field of medical practice regarding the advisability introduction of health insurance in the construction of new national health care system. Materials and Methods. Studied Ukraine's national legislation, the legislation of the Republic of Poland, comparative and legal method and other general scientific and special methods of scientific knowledge have been applied.

Results. One of anticorruption actions in health care system is introduction of obligatory social medical insurance. Following stages are: an effective control over financing of health care system; adoption of law of Ukraine «About obligatory social medical insurance» and creation of conditions for its coming into force of respective alterations of tax law; stimulation development of the state medical insurance.

Conclusions. The offered system of the measures directed on introduction and development of medical insurance in Ukraine, will allow to create conditions for the fullest satisfaction of requirements of the population in accessible and high-quality medical aid; essential reduce loading on state and local budgets; to reduce a share of shadow medicine in medical system; to avoid unreasonable expenses; to improve material motivation of workers.

KEY WORDS: corruption, offence, health insurance, health care system.

Рукопис надійшов до редакції 16.03.2015 р.

Відомості про авторів:

Рогальський Ігор Олегович - к.мед.н., доц. кафедри медичного права ДВНЗ «Тернопільський державний медичний університет імені І.Я. Горбачевського МОЗ України»; тел.: +38(0352)-52-72-33.

Калинюк Наталя Миколаївна - к.юр.н., доц. кафедри медичного права ДВНЗ «Тернопільський державний медичний університет імені І.Я. Горбачевського МОЗ України»; тел.: +38(0352)-52-72-33. 